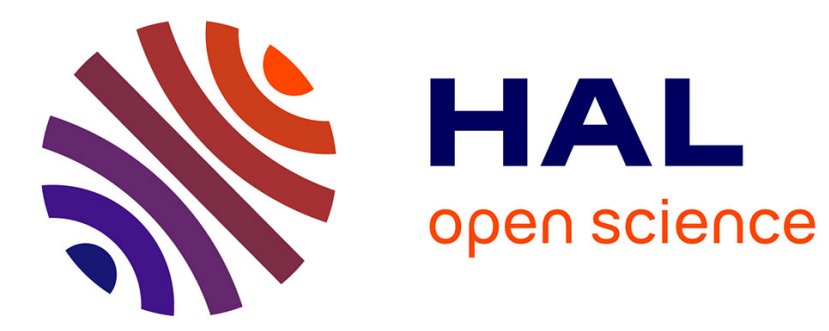

\title{
Giving in France: A Philanthropic Renewal after Decades of Distrust
}

\author{
Arthur Gautier, Anne-Claire Pache, Valérie Mossel
}

\section{To cite this version:}

Arthur Gautier, Anne-Claire Pache, Valérie Mossel. Giving in France: A Philanthropic Renewal after

Decades of Distrust. 2013. hal-00914805

\section{HAL Id: hal-00914805 \\ https://essec.hal.science/hal-00914805}

Preprint submitted on 6 Dec 2013

HAL is a multi-disciplinary open access archive for the deposit and dissemination of scientific research documents, whether they are published or not. The documents may come from teaching and research institutions in France or abroad, or from public or private research centers.
L'archive ouverte pluridisciplinaire HAL, est destinée au dépôt et à la diffusion de documents scientifiques de niveau recherche, publiés ou non, émanant des établissements d'enseignement et de recherche français ou étrangers, des laboratoires publics ou privés. 


\title{
Giving in France: A Philanthropic Renewal after Decades of Distrust
}

\author{
Research Center \\ ESSEC Working Paper 1318
}

2013

\author{
Arthur Gautier \\ Anne-Claire Pache \\ Valérie Mossel
}


Giving in France: A philanthropic renewal after decades of distrust

Arthur Gautier

ESSEC Business School

gautierart@essec.edu

Anne-Claire Pache

ESSEC Business School

pache@essec.edu

Valérie Mossel

Rotterdam School of Management

$\underline{\text { mossel@rsm.nl }}$ 


\section{The philanthropic landscape}

\subsection{History}

The history of the French philanthropic sector can be traced back to the middle ages, when the Catholic Church created charitable organizations devoted to the care and relief of underprivileged citizens (orphans, poor, or sick people). While these charitable organizations progressively secularized in a context of crisis of the welfare church, they organically developed until the end of the $18^{\text {th }}$ century.

The 1789 French revolution radically changed the philanthropic landscape, instituting the State as the sole ruler and custodian of the 'public interest' of the French people. The Le Chapelier Act of 1791 dissolved all existing charitable associations and nationalized all foundations under the principle that "no one is allowed to incite citizens to have an intermediary interest [between their own and the State's], to separate them from the Nation by spirit of cooperation."The 1793 republican constitution formally assignedthe responsibility of the welfare of French citizens to the State: "Society owes subsistence to the unfortunate citizens, either by getting them work or by insuring means of subsistence to those who cannot work."

Private philanthropic initiatives reemerged progressively - yet illegally - in the $19^{\text {th }}$ century, as the industrial revolution led to the emergence of new and pressing social needs for the working class (Archambault, 1997; Castel, 1995). It was only in 1901 that a law reinstituted the right for French citizens to create associations, i.e. nonprofit organizations allowing them to "pool their knowledge or their activities with a purpose different than making profits." The associative sector grew progressively during the $20^{\text {th }}$ century. Until the 1970 s, between 10000 and 20000 new associations were created per year; since 2000, more than 60000 new associations have been created per year(Tchernonog, 2007). This growthdemonstrates an increasing interest of French citizens for collective nonprofit action. Interestingly, foundations, as vehicles allowing for the mobilization of private assets in support of charitable causes, were not instituted back into French law until 1987, with subsequent laws in 1990, 2003 and 2008 progressively compensating for the historical lag of the French foundation sector (Observatoire de la Fondation de France, 2011).

During the $20^{\text {th }}$ century, the nonprofit sector repositioned itself vis-à-vis the State. This relationship progressively evolved from distrust and confrontation to complementarity. The French welfare State developed since the end of World War I, instituting in 1945 the French social security, providing all citizens with public financial support for illness, old age, unemployment and family expansion. In this new context, a sizeable number of associations became providers of social or medical services (for the elderly, for the disabled or for the poor) funded by social security funds. In the late 1960s, changes in mentalities led to a 'nonprofit boom' as citizens mobilized to voice and address new societal issues (Laville, 1994). Focusing first on themes like education and culture, nonprofit associations developed in the 1970s to promote feminism, environmentalism, political activism, human rights or international relief. In the late 1970s and 1980s, the emergence of structural unemployment and its associated social exclusion led associations to embrace issues of work integration and fight against poverty. Recognizing the important role played by these nonprofit organizations to generate social innovation and address key social issues in an effective way, the French State encouraged the development of the nonprofit sector, either as a partner of important social policies or as a substitute for public action. In the late $20^{\text {th }}$ century, this partnership was reinforced within the different levels of local government (cities, counties, regions).

In the wake of the $21^{\text {st }}$ century, the French nonprofit sector is vibrant, diversified and increasingly professionalized. Its dependence from public support is relatively high, yet cuts 
in public funds since late 2010 push for an increasing reliance of this sector on philanthropic resources, fees or commercial revenues.

\subsection{Size and scope of the nonprofit sector in France}

France leads OECD countries in public spending for social expenditures, which accounted for 32.1 percent of its GDP in 2010 - 10 percentage points higher than the OECD average (OECD, 2010). Meanwhile, the French nonprofit sector is relatively large and has grown steadily in the past 50 years. This is characteristic of the 'corporatist model' as proposed by Lester Salamon and Helmut Anheier in their influential works on comparing civil society across countries (Salamon \& Anheier, 1997; Salamon, Sokolowski, \& Anheier, 2000). In this model, associations and foundations may be portrayed as " "pre-modern mechanisms that are deliberately preserved by the state in its efforts to retain the support of key social elites while pre-empting more radical demands for social welfare protections" (Salamon et al., 2000, p. 17). In France, the State maintains a central role in providing public goods and services, but it has relinquished absolute monopoly over the public interest, allowing the nonprofit sector to grow alongside (Archambault, 1997, 2000).

The nonprofit sector in France can be roughly divided in two categories of philanthropic organizations: associations, which are the main beneficiaries from philanthropy and non-governmental providers of public goods and services; and foundations, which are the major grant-making organizations and supplementary providers of public goods and services. We left out 'non-philanthropic' organizations that are often included in the nonprofit sector in France but do have commercial activities, such as mutual companies and cooperatives.

\subsubsection{Associations}

Associations are nonprofit organizations formed by a group of individuals to accomplish a purpose in common. They are extremely easy to create and administer, and have been used extensively by French people to undertake countless nonprofit activities. In 2012, there were roughly 1.3 million associations in France, with annual expenses of 90 billion U.S. dollars. 23 million French people (45 percent of adults) are members of at least one association, with sport, culture, and leisure representing the bulk of memberships (Archambault \& Tchernonog, 2012; Tchernonog, 2007).

Noticeably, only 165,000 out of 1.3 million associations employ staff, with a national estimation of 1.8 million permanent staff ( 1 million full-time equivalents), representing 5 percent of French workforce payroll. Volunteering is very developed in associations, especially in those without paid staff. It is estimated that 16 million French people (32 percent of adults) are active volunteers in one or several associations, accounting for another million full-time equivalents. Their responsibilities vary from mundane operational tasks to executive functions and legal responsibility, with many associations struggling to find qualified volunteers on their boards (Ferrand-Bechmann, 2000).

One of the key challenges to understanding the nonprofit sector and philanthropy in France is the great heterogeneity across organizations set up as associations. Using data regarding employment, volunteering, annual budgets, and resources, Tchernonog(2000) proposed to classify French associations along three types: operating associations which provide social services anddepend widely on public funding, activist associations relying heavily on philanthropic giving, and associations serving their members where fees for services are the main resources. Other scholars remarked the recent emergence of new forms of associations undertaking market-like activities (Hély, 2004). 


\subsubsection{Foundations}

Foundations are 'asset-based' nonprofit organizations through which one or more individuals or legal entities irrevocably allocate property, rights or resources for activities of public interest. The oldest active foundations were created in the $19^{\text {th }}$ century, but it is only since 1987 that foundations have a legal status in France. There has been much State control over the creation and operation of foundations, which explains their relative meager number (Rozier, 2007). Today, there are about 2,500 foundations in France, a sharp increase since 2001 (+104 percent) whenabout 1,100 were identified. Their assets amount to about 18 billion U.S. dollars, with 6.5 billion U.S. dollars of annual expenses. Foundations employ an estimated 60,000 of staff (Observatoire de la Fondation de France, 2011). Recent growth in numbers, assets, and expenses has been fueled by legal advances in the past 10 years which have considerably loosened the grip over foundations.

Regulative complexity and subtle distinctions in the French foundations landscape are well beyond the scope of this article. However, it is useful to distinguish two broad types of foundations in France: operating foundations, which fund their own activities - mainly through the product of their assets - and grant-making foundations, which fund and support other organizations - often associations. The former is the older of the two models and represents 70 percent of French foundations - as well asmost of foundation staff in France, while the latter accounts for 30 percent(Observatoire de la Fondation de France, 2011). The proportion of grant-making foundations has sharply increased for the past 20 years: in 1990, only 3 percent of French foundations were distributing grants (Archambault, 1997). Also, a new law passed in 2003 allowed 'spending down' for French foundations, which can now use a portion of their assets to fund their activities.

As the principal organized vehicles for philanthropy, associations and foundations are only the tip of iceberg, though. Indeed, many donors neither set up an organization nor declare their gifts. Only a fraction of philanthropy is thus visible. Meanwhile, if one defines philanthropy as all "private means to public ends" (Sulek, 2010), one should also include resources given away by all types of organizations, including businesses.

\subsection{Government policy in the nonprofit sector}

\subsubsection{Government subsidies}

The Johns Hopkins Comparative Nonprofit Sector Project is arguably the only data source to compare the characteristic of nonprofit organizations across countries. There are great variations in many respects, but one of the most interesting discrepancies concerns revenue sources for "civil society organizations." Aggregated data for 38 countries show this average equilibrium: 53 percent of revenues come from fees, 35 percent from government, and 12 percent from philanthropy (Salamon, Anheier, List, Toepler, \& Sokolowski, 1999).

At first sight, France's scorecard does not differ much from these global figures. According to the latest data available, associations get 49 percent of their revenues from fees for services, 34 percent for public subsidies, 12 percent for membership dues, and 5 percent from philanthropy (Tchernonog, 2007). However, contrary to Salamon et al., Tchernonog counts public contracts and public orders in the "fees for services" category, instead of combining them with "public subsidies" to form a global "government" category. In 1999, French data from the Johns Hopkins Comparative Nonprofit Sector Project found associations to get 58 percent of revenues come from government, 34 percent from fees, and 8 percent from philanthropy (Salamon et al., 1999, p. 90). Indeed, public sector payments are dominant

\footnotetext{
${ }^{1}$ Broadly defined as private, nonprofit distributing, self-governing and voluntary organizations. This includes but is not limited to associations and foundations.
} 
in the French nonprofit sector, coming from social security, central government and local governments. There are, of course, variations between the various fields or domains covered. For instance, health services are massively funded by government ( 80 percent) while international activities draw heavily from both government (43 percent) and philanthropy (40 percent). Fees are dominant in fields such as culture ( 65 percent of revenues) and development (61 percent) (Salamon et al., 1999, p. 88).

As in other Western countries, nonprofit organizations in France face a difficult financial situation. First, government subsidies have either stagnated or changed in nature. The State has transferred many responsibilities to regional and local governments, including subsidies for nonprofit organizations. Meanwhile, governments have increasingly relied on contracts and calls for projects instead of mere subsidies to cover overheads (Archambault \& Tchernonog, 2012). Second, the economic downturn has increased the demand for welfare services, as many poor people have been hit by the recession. Nonprofit organizations must address more needs with fewer resources, and a wave of mergers, budget cuts and restructuration of the sector is underway (Archambault, 2011).

More recent data show that nonprofit organizations depend less on government subsidies and more on fees from activities. Philanthropy, both from individuals and corporations, has gained momentum over the past 10 years after a long period of obscurity and illegitimacy. However, philanthropic funds still account for only 5 to 10 percent of revenue sources for French nonprofit organizations. We are left to wonder the extent to which philanthropy can develop as an alternative resource for nonprofit organizations.

\subsubsection{Fiscal incentives}

France is among the OECD countries with the highest tax and social security burden on income. After decades of steady growth since World War II, the French welfare state is now characterized by its spending outpacing its revenues, like several fellow OECD countries. The government has limited options to raise revenues without decreasing spending, since tax rates and public debt have already reached very high levels. Cuts in public spending are underway, though less quickly than in other countries facing similar difficulties. Public subsidies for nonprofit organizations are under strong pressure, while alternative ways to finance their activities are increasingly sought after.

In this context, philanthropy has become a key complementary resource for nonprofit organizations. The French state now encourages philanthropy with generous fiscal incentives. Actually, France went from almost zero incentive in the 1980s to one of the most encouraging exemptions systems for both individual and corporate philanthropy. After two laws in 1987 and 1990, a milestone was reached with the 2003 law on philanthropy, associations and foundations. Among other aspects, it increased the rates and amounts of fiscal exemptions. Since 2003, households can deduct 66 percent of their gifts from their income tax, in the limit of 20 percent of all taxable incomes. Corporations can deduct 60 percent of their gifts from their corporate tax, within 0.5 percent of their earnings before taxes. The law adds an additional fiscal incentive to encourage firms to buy 'national treasures' on behalf of the state. To our knowledge, there is no available data on the rate of use of these fiscal incentives.

With the public debt crisis looming and the necessity to cut public spending, these fiscal incentives have been under heavy scrutiny for the past few years by administration and government officials. Professional organizations have voiced their concerns and lobbied for the maintenance of tax incentives for philanthropy. So far, the government has not made changes, but it is uncertain how long this will remain true. 


\subsection{Regulation of the nonprofit sector}

While it is very easy to create and administer an association in France, it is strongly recommended to declare any new association to the prefecture (local state administration) in order for it to have legal personality. Undeclared associations cannot use bank accounts, receive subsidies, or sue in courts. Foundations are more difficult to create and must also be declared to have legal personality.

Only certain types of nonprofit organizations are eligible to the favorable fiscal incentives outlined above. More precisely, only eligible organizations are able to deliver 'fiscal receipts' to donors (either individuals or corporations) who wish to benefit from tax exemptions. To be eligible, three criteria must be met. The organization should 1) act in the 'public interest' (i.e. not being a members' club, not seeking profits through lucrative activities), 2) have part of is activities in France, and 3) operate in a field that belongs to a list issued in the French Tax Code (education, science, social welfare, culture, sports...). The French state does not control a priori but a posteriori, on a random basis. Organizations that are unsure whether they meet these criteria can ask for a 'tax ruling' before issuing fiscal receipts to their donors. Through its Interior Ministry, the French state collects fiscal receipts completed by donors and keeps track of statistics for household and corporate giving, though only a minority of gifts seems to solicit these tax incentives.

\subsection{Culture}

\subsubsection{Religion}

France is a secular State since a 1905 law instituted the separation of Church and State, stating that "the Republic neither recognizes, nor employs or subsidizes any worship. Accordingly, any expenses relative to the exercise of the worship will be eliminated from national, local, and municipal budgets."Catholicism is the dominant religion in France, yet the rate of religious practice in France is relatively low and decreasing (Niel, 1998). Data on religious affiliation is difficult to assess since, based on the principle of freedom of religion, the French State refrains from asking citizens about their religious affiliation in the national census. A recent survey (IFOP, 2011) indicates that 65 percent of the French population claims to beCatholic, 25 percentwithout religion, 6 percent Muslim, 2 percent Protestant, 1 percent Jew and 1 percent other. While other surveys may produce slightly different data, all recognize a decrease in religious practice since the end of the Second World War as well as a diversification of religious affiliation (mainly Islam and Evangelism) through immigration. Only 16 percent of the French citizens reported "a regular religious practice" (Régnier-Loilier $\&$ Prioux, 2008). The French nonprofit sector is remarkably more secular and less permeated by religion than in other Western countries, notably the United States (Archambault, 2011).

Despite this decrease, Catholicism still influences French culture, shaping not only its cities and landscapes with religious edifices, but also its culture with important values and traditions. Among such is philanthropy. In the Catholic dogma, wealth has always been met with suspicion. Famously, the Bible contains verses attacking the rich who accumulate wealth instead of giving it away to those most in need: "Again I tell you, it is easier for a camel to go through the eye of a needle than for a rich person to enter the kingdom of God" (Matthew 19:24). This 'anti-rich' mentality is still prevalent in France. Unlike Protestantism, good works like charitable donations are encouraged as a means to redistribute wealth in society and to attain salvation as an individual. Importantly, privacy about giving is recommended for Catholics since gifts should be motivated by spirituality rather than reputation (Destrée, 2012). While giving is a part of the French culture - particularly for Catholics, and more 
broadly, citizens with religious beliefs - it thus remains a relatively confidential practice in France.

\subsubsection{Political Culture}

The French political culture is characterized by a conception of the State, rooted in the French Revolution, as the achievement of the collective interest of the French people. As such, the State is still very much considered today by French citizens as the guarantor of this collective interest as well as the fair provider of welfare protection for all citizens. While taxes are conceived as the way through which citizens provide the State with the means to ensure that provision, philanthropic giving is not viewed as part of the duties of the French citizen.

Importantly, this political culture does not keep French citizens from giving since 56 percent are reported to make gifts to charitable causes. While this proportion remains relatively stable over time, the giving households have increased their gifts in the last years despite the financial crisis (France Générosités \& CerPhi, 2012).

\subsubsection{Professionalism of Fundraising}

1.5.2.1Organization of fundraising

Various French nonprofit organizations rely on individual and corporate giving. France Generosities [France Generosités] is the union of associations and foundations which raises all types of philanthropic funds. Its mission is to promote generosity by encouraging the development of policies supporting the development of philanthropy. It encourages fair, efficient and transparent fundraising practices as well as provides legal and practical advice to its members in order to enhance their ability to raise funds effectively. The French Association of Fundraisers [Association Française des Fundraisers; AFF] is a major network of fundraising and philanthropy professionals. Its mission is to train and inform professional fundraisers as well as to provide them with stimulating networking activities. It promotes effective as well as ethical practices in fundraising. Additionally, the Charter's Committee [Le Comité de la Charte] is a voluntary initiative by leading organizations raising philanthropic funds from the general public to develop a fundraising code of conduct, as guaranteed by a label. The organization audits its members to assess whether they respect the code and broadly promotesethical standards in the fundraising industry.

The major French fundraising organizations rely on a wide variety of solicitation techniques, ranging from direct mailing, to street-marketing, fundraising events, internet and major donor campaigns. Charitable bequests represent a sizeable source of revenue for a few large and visible organizations. In 2010, 75 percent of gifts were made by check, while 25 percent were made through direct debit from bank accounts, thus reflecting the acceptance of recurrent giving by French donors. In the same year, internet campaigns generated 3 percent of total giving (France Générosités \& CerPhi, 2012). A few major events draw a lot of philanthropic attention. The most visible one, the Telethon, organized by the French Association against Myopathy [Association Française de Luttecontre les Myopathies; AFM], is a 30-hour TV show which has collected up to 130 million U.S. dollars for AFM annually.

\subsubsection{Major donors}

Given the cultural context described above, major donors are relatively rare in France, and when they exist, they typically like to remain anonymous. However, due to a favorable fiscal regime for gifts since 2003, a growing awareness of the limitations of public funding, and powerful calls for action such as the Giving Pledge which have all drawn public attention to the issue of philanthropy, a few major French philanthropists have begun to communicate 
their initiatives to the public. The media, which has long been skeptical about philanthropy, has recently depicted these philanthropists in more favorable ways (Seghers, 2009).

A 2011 survey indicates that households earning more than 58,000 U.S. dollars per year represent 27 percent of giving households and contribute 48 percent of all gifts, with an average sum of 808 U.S. dollars. When turning to even more affluent households, i.e. those earning more than 260,000 U.S. dollars per year, 51 percent of them report giving with average gifts of 4,030U.S. dollars, compared to the average gift of 460U.S. dollars for all French households (France Générosités \& CerPhi, 2012). More specific data about major gifts remain, as of now, unavailable.

\subsubsection{The role of financial advisory professionals}

The professional infrastructure of philanthropy has long remained underdeveloped in France, with a few major exceptions including the France Foundation[Fondation de France] or the French Center for Trusts and Foundations [Centre Français des Fonds et Fondations], which have enjoyed a monopoly on philanthropy advisory in France until recently. For the past few years, major private banks, including BNP Paribas Wealth Management and UBS, as well as professional service firms such as KPMG and Ernst \& Young, have developed expertise in philanthropy in order to advise their clients on how to best manage their philanthropic initiatives. In 2012, the French Association of Family Offices [Association Française des Family Offices] published a practical guide about philanthropy for family officers. A small network of independent consultants also recently blossomed, offering philanthropic advisory to wealthy individuals.

\section{Philanthropic giving in France}

\subsection{Data and methods}

The French data were collected by market research firm TNS Sofres. Between January 30 and February 19, 2009, 4,612 French households regularly participating in survey research were invited to participate in an online survey using CASI (Computer Assisted Self Interviewing $)^{2}$. After 1,195 respondents filled out the questionnaire, the survey closed for further participation. The data was weighted for the characteristics age, gender, social class, region and household size to make it representative for the French population.

The dependent variable in the analyses is the natural log of the total amount of money that a household donated to charitable organizations in 2009. The Giving France Study measures donations made to ten charitable sub-sectors: civic rights and advocacy, culture, arts and humanities, education and research, health, international assistance, environment and animals, religion, social services, sport and recreation and other charitable causes. First respondent were questioned regarding which method they used to make a donation, for example through a personal letter, the internet or a door-to-door collection. Secondly, respondents were asked whether or not their household made a donation to each of the subsectors. Thirdly, the respondents were asked to state the exact amount of money given to each sub-sector in 2009.

\footnotetext{
${ }^{2}$ Mistakenly, the 4,511 respondents initially invited to participate in the survey were selected based on a previously answered question about doing "most of the shopping in the household". Only respondents who indicated to do most of the shopping in their household were invited to participate in the survey. After 1,000 respondents filled out the survey, it closed for further participation. To correct for the selection error, a second group of 1,110 respondents (who had previously indicated to "not to do most of the shopping in the household") were invited to participate on February 18 and 19. This resulted in another 195 responses, after which the survey was again closed for further participation.
} 


\subsection{Descriptive results}

In 2010, French households declared donating 1.95 billion EUR (approximately 2.5 billion U.S. dollars) which is about 0.09 percent of the GDP(France Générosités \& CerPhi, 2012). A 2006 comparative study estimated giving in France at 0.14 percent of the GDP, including bequests(CAF, 2006). In the Giving France Study (2009) 66 percent of the French households indicate to have made at least one donation to nonprofit organizations in 2009. The average household donated 251 U.S. dollars. Table 7.1 displays the percentage of donors and the mean amount donated in 2010 by French households for a variety of causes, and thus provides interesting patterns to study.

As expected, religious giving is much less widespread than secular giving in France. Only 14 percent of French households donated to religious causes with an average yearly amount of 163 U.S. Dollars, while almost two thirds of households donated to secular causes (64 percent). The French households donated most frequently to organizations active in the health sector (37 percent), like those supporting medical research (AFM Téléthon, Liguecontre le Cancer), providing basic healthcare services(Croix Rouge), ormanaging hospitals and specialized institutions. The average amount donated by households to organizations in the health sector is rather low (95 U.S. dollars) compared to other causes. Given the reliance of the French healthcare sector on public funds targeted to the funding of infrastructures (hospitals, medical equipment) and salaries of medical staff, philanthropy in health mostly targeted scientific research and relief, with gifts of all sizes but a majority of small gifts by households.

The second most frequent destination of gifts is public and social benefit organizations, supported by 25 percent of French households. The two leading organizations are Secours Catholique-Caritas France (religious) and Les Restos du Coeur (secular), both active in providing assistance and services to the needy. With 19percent, international reliefwas the third most frequently supported cause. Médecins Sans Frontières is probably the most renowned of these organizations and provides emergency medical carein countries hit by natural catastrophes, armed conflicts, or pandemics. Other international relief organizations focus on human rights and more long-term development activities. Further, 15 percent of the French households indicated to have made a donation to education and research. Examples includeprimary and secondary nonprofit schools under contract with the Education Ministry, as well as alumni giving to their alma mater, though this phenomenon is only nascent in France. Finally, 12 percent of the households donated to organizations active in the field of environment, wild life and animal protection, including activist NGO Greenpeace France.

Interestingly, while the organizations focusing on civic rights and advocacy, sports and recreation as well as culture and arts attracted fewer gifts from French households, they received relatively larger gifts: on average, households donated 148 U.S. dollars to civic rights and advocacy organizations, 130 U.S. dollars to sports and recreation and 154 U.S. dollars to arts and culture organizations. On average, French households donated 224 U.S. dollars to all secular causes in 2009.

Table 7.1 Percentage of donors and average amount donated among donors to different charitable sectors in France 2009 (N=1,195; Giving France Study 2009)

\begin{tabular}{lrr} 
& \%of donors & Conditional donation (U.S. dollars) \\
\hline Health & 37 & 95 \\
International relief & 19 & 114 \\
Nature, environment and & 12 & 79 \\
animals & 25 & 91 \\
Public and social benefits & 25
\end{tabular}


Sports and recreation $\quad 7$

Culture and arts 6

Education and research $\quad 15$

$\begin{array}{lcr}\text { Civic rights and advocacy } & 8 & 149\end{array}$

Other causes 11

\subsection{Explaining philanthropic giving in France}

In this paragraph we look at the relationship between characteristics known to influence philanthropic behavior and the likelihood and amount people give to all charitable organizations, religious and secular.

\subsubsection{Incidence of giving}

Table 7.2 displays the results of logistic regression analyses of whether or not people give to any charitable cause (total giving), to religious causes and to secular causes. Overall, our data suggest that 66 percent of the French population made a donation to any charitable organization over the course of 2009. Age seems to influence whether or not people give. In our sample, people between 35 and 65 had a 33 percent higher probability to donate to a nonprofit organization than people younger than 35. People aged over 65 had a 118 percent higher probability to donate in comparison to people under 35 . Those who completed secondary education had a 48 percent higher probability to donate to a charitable cause than someone with exclusively primary education. However, completing tertiary education did not have much influence over donation behavior. Also gender and marriage did not seem to influence the likelihood to give.

Our data further shed light on the relationship between wealth and giving. In our sample, households earning 10,000 U.S. dollarsor more in revenues than average had a 7 percent higher probability to donate to a nonprofit organization. Meanwhile, those who owned a house had a 35 percent higher probability of making a donation.

Our data further suggest that religious affiliations are leading determinants of giving. In France, Roman Catholics are 76 percentmore likelythan non-religious people to give. In contrast, being Protestant or affiliated with another religion (i.e. other Christian denomination, Jewish, Islamic, Eastern religion, etc.) did nothave an influence on an individual's likelihood to make a donation, as compared tonon-religious people. Neither did attendance of religious services. An even stronger determinant of giving than religion is generalized trust, namely trust towards strangers in society, beyond face-to-face interactions with already known partners. People who tend to trust others had a 196 percenthigher probability to give, compared to those who reported no generalized level of trust.

Interestingly, these results overall hold for gifts made specifically to secular organizations (with the exception of secondary education, which did not seem to have an influence on whether or not one has the intention to donate). Yet total giving patterns sharply differed from religious giving patterns, suggesting that the drivers to give to religious organizations may be very specific. For instance, our analysis suggests that age, education, gender or marital status did not have an influence on the likelihood to give to religious organizations. Gifts to religious organizations were more likely made by wealthier households, earning 10,000 U.S. dollars more than average ( +5 percent) as well as by homeowners ( +73 percent). Unsurprisingly, affiliation with religious denominations seemedto be the strongest drivers for gifts to religious organizations. In our sample, people belonging 
to the Roman Catholic Churchwere more likely (by 389 percent)to make gifts to religious organizations. These results also hold for Protestants (+ 559 percent) and other religious affiliations ( +557 percent), as well as for those attending religious services $(+19$ percent $)$.

Table 7.2 Logistic regression analysis of total, religious and secular giving in the France in 2009 (N=1,195; Giving France Study 2009)

\begin{tabular}{|c|c|c|c|c|c|c|c|c|c|}
\hline & \multicolumn{3}{|c|}{ Total giving } & \multicolumn{3}{|c|}{ Religious giving } & \multicolumn{3}{|c|}{ Secular giving $^{4}$} \\
\hline & $\mathrm{B}$ & S.E. & $\begin{array}{l}\text { Odd } \\
\text { s } \\
\text { ratio }\end{array}$ & $\mathrm{B}$ & S.E. & $\begin{array}{l}\text { Odd } \\
\text { s } \\
\text { ratio }\end{array}$ & $\mathrm{B}$ & S.E. & $\begin{array}{l}\text { Odd } \\
\mathrm{s} \\
\text { ratio }\end{array}$ \\
\hline Constant & $-0.76^{* *}$ & & 0.47 & $\begin{array}{l}- \\
3.98 * \\
*\end{array}$ & 0.36 & 0.02 & $\begin{array}{l}- \\
0.79 * \\
*\end{array}$ & 0.20 & 0.45 \\
\hline Aged under 35 (ref.) & - & - & - & - & - & - & - & - & - \\
\hline Aged between $35-65$ & $0.28^{(+)}$ & 0.16 & 1.33 & 0.05 & 0.27 & 1.05 & $0.32 *$ & 0.16 & 1.37 \\
\hline Aged over 65 & $0.78 * *$ & 0.24 & 2.18 & 0.39 & 0.33 & 1.48 & $\begin{array}{l}0.77 * \\
*\end{array}$ & 0.24 & 2.17 \\
\hline $\begin{array}{l}\text { Primary education } \\
\text { (ref.) }\end{array}$ & - & - & - & - & 0.22 & - & - & - & - \\
\hline Secondary education & $0.40 * *$ & 0.15 & 1.48 & 0.15 & 0.27 & 1.17 & 0.40 & 0.15 & 1.49 \\
\hline Tertiary education & 0.22 & 0.19 & 1.25 & -0.04 & 0.19 & 0.96 & 0.23 & 0.19 & 1.26 \\
\hline Male & -0.03 & 0.04 & 0.97 & 0.32 & 0.21 & 1.37 & -0.87 & 0.13 & 0.92 \\
\hline Married & 0.21 & 0.15 & 1.23 & 0.24 & 0.00 & 1.27 & 0.14 & 0.15 & 1.15 \\
\hline $\begin{array}{l}\text { After tax household } \\
\text { income }^{1}\end{array}$ & $0.06^{*}$ & 0.03 & 1.07 & $0.04^{(+)}$ & 0.25 & 1.05 & $0.07 *$ & 0.28 & 1.07 \\
\hline Home ownership & $0.30^{*}$ & 0.14 & 1.35 & $0.55^{(+)}$ & 0.22 & 1.73 & $0.30 *$ & 0.14 & 1.35 \\
\hline Not religious (ref.) & - & - & - & - & - & - & - & - & - \\
\hline Roman Catholic & $0.57 * *$ & 0.15 & 1.76 & $\begin{array}{l}1.59 * \\
*\end{array}$ & 0.22 & 4.89 & $\begin{array}{l}0.45 * \\
*\end{array}$ & 0.14 & 1.57 \\
\hline Protestant & 1.25 & 0.76 & 3.48 & $\begin{array}{l}1.89 * \\
*\end{array}$ & 0.57 & 6.59 & 0.86 & 0.65 & 2.36 \\
\hline $\begin{array}{l}\text { Other religious } \\
\text { affiliation }\end{array}$ & 0.23 & 0.25 & 1.26 & $\begin{array}{l}1.88^{*} \\
*\end{array}$ & 0.32 & 6.57 & 0.26 & 0.25 & 1.3 \\
\hline Religious attendance $^{2}$ & 0.05 & 0.04 & 1.05 & $\begin{array}{l}0.18^{*} \\
*\end{array}$ & 0.03 & 1.19 & 0.02 & 0.03 & 1.02 \\
\hline Generalized trust ${ }^{3}$ & $1.08 * *$ & 0.21 & 2.96 & 0.45 & 0.37 & 1.56 & $\begin{array}{l}1.07 * \\
*\end{array}$ & 0.26 & 2.92 \\
\hline
\end{tabular}

Notes: ${ }^{1}$ After tax household income in U.S. dollar/10,000; ${ }^{2}$ Religious service attendance in times a month; ${ }^{3}$ scale $0-1 ;{ }^{4}$ secular giving comprises of giving to organizations in the fields of health, international relief, nature, environment and animals, public and social benefits, sports and recreation, culture and arts, education and research and 'other' causes; ${ }^{* *} p \leq 0.01$; * $p \leq 0.05{ }^{(+)} p \leq 0.10$.

\subsubsection{Amount donated}

We further analyzed our data for the relationship between various factors and the amountsgiven. Table 7.3 displays the results from a Tobit regression analysis of the natural $\log$ of the total amount people gave to any charitable cause, to religious charitable causes and to secular charitable causes in 2009. 
Ourresults suggestthat age influences the level of total philanthropic donations as older people seem to give more. In our sample, individualsbetween 35 and 65 were shown to donate 56 percent more money compared to thoseunder 35 . Individuals over 65 were further shown to donate 135 percent more money than the reference group under 35 . Interpretations of these findings may concur that older people have both more time and more accumulated wealth than younger people, and are thus more likely to give than younger people, who have to provide for themselves and their families in a contracting economy.

The amount of the gifts further seemed to increase with the degree of education. Individuals who completed secondary and tertiary education were predicted to give more,compared to those who only completed primary education or less. In contrast, gender and marital status did not affect the level of philanthropic donations.

Unsurprisingly, our results further suggest that income is positively related to the amount donated to philanthropic organizations. People with high revenues (earning 10,000 U.S. dollars more than average) were shown to make larger gifts by 7 percent. People who own their home were also likely to give 41 percent more money to charitable causes than people who do not.

Likewise, religious affiliation and attendance related positively to the level of philanthropic giving. People who belong to the Roman Catholic Church werepredicted to donate 65 percent more than those without religions affiliation. Following the same pattern, people affiliated with Protestantism and other religions donated 114 percent and 54 percent more than those who are not religiously affiliated, respectively. Stronger religious attendance related to higher philanthropic giving as well. Attending religious services oncea month or more related to 7 percent higher predicted giving. Finally, people who scored high on generalized trust (i.e. who tend to trust others in society)are predicted to give 137 percent more money to nonprofit organizations than people who tend to distrust other people.

Except for some minor changes, the results for amount donated to secular organizations strongly resemble the results for total giving. However, religious giving presents different patterns than total giving. A few influential variables in the case of giving to all organizations did not seem to have any impact on the amounts donated to religious organizations.In our sample, gender, marital status, education and trust did not seem to impact the amount of religious giving. While age seemed to be a factor, it was only the case for individuals above 65 , who were predicted to donate 22 percent more to religious organizations than individuals under 35.Income and homeownership seem to influence the amount of gifts made to religious organizations, to a lesser extent, however, then gifts made to all organizations. As expected, religious affiliation was positively related to the amounts of religious giving. Roman Catholics were predicted to give 67 percent more, Protestants were predicted to give 89 percent more and people affiliated to another religion were predicted to give 86 percent more, all compared to those who are not religiously affiliated. People who attend religious services donated 6 percent more toreligious nonprofit organizations.

Table 7.3 Tobit regression analyses of the natural log of the total amount donated in France in 2009 (N=1,195; Giving France Study 2009)

\begin{tabular}{lcccccc}
\hline & $\begin{array}{c}\text { Log amount of } \\
\text { total giving }\end{array}$ & $\begin{array}{c}\text { Log amount to } \\
\text { religious giving }\end{array}$ & \multicolumn{2}{c}{$\begin{array}{c}\text { Log amount to } \\
\text { secular giving }\end{array}$} \\
\hline $\begin{array}{l}\text { Marginal } \\
\text { effect }\end{array}$ & S.E. & $\begin{array}{c}\text { Margin } \\
\text { al } \\
\text { effect }\end{array}$ & S.E. & $\begin{array}{c}\text { Margin } \\
\text { al } \\
\text { effect }\end{array}$ & S.E. \\
\hline $\begin{array}{l}\text { Constant } \\
\text { Aged under 35 (ref.) }\end{array}$ & - & - & - & - & - & - \\
\hline
\end{tabular}




\begin{tabular}{|c|c|c|c|c|c|c|}
\hline Aged between 35-65 & $0.56 * *$ & 0.20 & 0.06 & 0.11 & $0.58 * *$ & 0.20 \\
\hline Aged over 65 & $1.357 * *$ & 0.27 & $0.22^{(+)}$ & 0.14 & $1.32 * *$ & 0.27 \\
\hline Primary education (ref.) & - & - & - & - & - & - \\
\hline Secondary education & $0.60 * *$ & 0.18 & 0.04 & 0.09 & $0.59 * *$ & 0.18 \\
\hline Tertiary education & $0.62 * *$ & 0.22 & -0.00 & 0.11 & $0.60 * *$ & 0.23 \\
\hline Male & 0.04 & 0.16 & 0.12 & 0.08 & -0.04 & 0.16 \\
\hline Married & 0.27 & 0.17 & 0.12 & 0.08 & 0.20 & 0.17 \\
\hline $\begin{array}{l}\text { After tax household } \\
\text { income }^{1}\end{array}$ & $0.07 * *$ & 0.03 & $0.02^{(+)}$ & 0.01 & $0.07 * *$ & 0.03 \\
\hline Home ownership & $0.41^{*}$ & 0.17 & $0.21 *$ & 0.09 & $0.42 *$ & 0.17 \\
\hline Not religious (ref.) & - & - & - & - & - & - \\
\hline Roman Catholic & $0.64 * *$ & 0.17 & $0.67 * *$ & 0.10 & $0.50 * *$ & 0.17 \\
\hline Protestant & $1.14^{(+)}$ & 0.61 & $0.89 * *$ & 0.25 & 0.61 & 0.62 \\
\hline Other religious affiliation & $0.54^{(+)}$ & 0.30 & $0.86^{* *}$ & 0.15 & 0.45 & 0.30 \\
\hline Religious attendance $^{2}$ & $0.07 *$ & 0.03 & $0.06 * *$ & 0.01 & 0.03 & 0.03 \\
\hline Generalized trust ${ }^{3}$ & $1.37 * *$ & 0.30 & 0.16 & 0.15 & $1.37 * *$ & 0.31 \\
\hline
\end{tabular}

Notes: ${ }^{1}$ After tax household income in U.S. dollar/10,000; ${ }^{2}$ Religious service attendance in times a month; ${ }^{3}$ scale $0-1 ;{ }^{4}$ secular giving comprises of giving to organizations in the fields of health, international relief, nature, environment and animals, public and social benefits, sports and recreation, culture and arts, education and research and 'other' causes; ${ }^{* *} p \leq 0.01$; ${ }^{*} p \leq 0.05 ;{ }^{(+)} p \leq 0.10$.

\section{Conclusion}

After centuries of State coercion towards philanthropy and a general distrust for all private initiatives for public interest, France has witnessed the rapid emergence of an increasingly favorable context to giving, especially in the past decades. Fiscal incentives and new juridical tools, together with the professionalization of nonprofit actors, have spurred philanthropy to new heights. While many donors remain anonymous, a growing number of philanthropists have started to talk openly about their giving. Pragmatic considerations in the face of contractions of government support and growing social needs have also contributed to this philanthropic renewal, though average and total donations remain relatively small compared to other Western countries.

However, with the public debt crisis and a stagnant economy, French authorities have recently considered reducing fiscal incentives while adding to the already heavy tax burden. There are growing concerns among nonprofit leaders that a "philanthropic crash" may be ahead if the government follows this path. Another concern is the demographics of giving in France. Typical French donors are old, educated and religious people, who have above average revenues, own their homes, and have high level of trust towards others in society. It remains to be seen whether younger generations, who - except for education -clearly depart from the average donor's profile, will be able or willing to further the growth of philanthropy in the years to come.

\section{References}

Archambault, E. (1997). France. In L. M. Salamon \& H. K. Anheier (Eds.), Defining the Nonprofit Sector: A Cross-National Analysis (pp. 103-127). Manchester University Press

Archambault, E. (2000). Perspective internationale sur le secteur sans but lucratif. Ceras revue Projet, 264. Retrieved from http://www.ceras-projet.com/index.php?id=1986 
Archambault, E. (2011). Les institutions sans but lucratif hier et aujourd'hui $\square$ : comparaison France-Etats-Unis. The Tocqueville Review, XXXII, 81-98.

Archambault, E., \& Tchernonog, V. (2012). Repères sur les associations en France. Paris: Conférence permanente des coordinations associatives. Retrieved from http://cpca.asso.fr/wp-content/uploads/2012/05/les-associations-en-franceaujourdhui.pdf

CAF. (2006). International comparisons of charitable giving (Briefing Paper) (p. 24). Kent: Charities Aid Foundation.

Castel, R. (1995). Les Métamorphoses de la question sociale: Une chronique du salariat. Fayard.

Destrée, J.-M. (2012). La dimension religieuse en France et en Europe. Revue des Deux Mondes, 108-116.

Ferrand-Bechmann, D. (2000). Le métier de bénévole. Anthropos.

France Générosités, \& CerPhi. (2012). Evolution de la générosité en France (p. 37). Paris.

Hély, M. (2004). Les différentes formes d'entreprises associatives. Sociologies Pratiques, $27-$ 51.

IFOP. (2011). Les Français et la croyance religieuse (Sondage IFOP pour le Journal du Dimanche) (p. 10). Paris: IFOP.

Laville, J.-L. (Ed.). (1994). L'économie solidaire: une perspective internationale. Paris: Desclée de Brouwer.

Niel, X. (1998). L'état de la pratique religieuse en France. Insee Première, 4.

Observatoire de la Fondation de France. (2011). Les fonds et fondations en France de 2001 à 2010. Paris: Fondation de France.

OECD. (2010). Public and private social expenditure in percentage of GDP in 2009. Retrieved from http://www.oecd.org/social/soc/socialexpendituredatabasesocx.htm

Régnier-Loilier, A., \& Prioux, F. (2008). La pratique religieuse influence-t-elle les comportements familiaux? Population et Sociétés, 1-4.

Rozier, S. (2007). France. In H. K. Anheier \& S. Daly (Eds.), The Politics of Foundations: A Comparative Analysis (p. 157-171). London: Routledge.

Salamon, L. M., \& Anheier, H. K. (1997). Defining the Nonprofit Sector: A Cross-national Analysis. Manchester University Press.

Salamon, L. M., Anheier, H. K., List, R., Toepler, S., \& Sokolowski, S. W. (1999). Global Civil Society: Dimensions of the Nonprofit Sector. Kumarian Press.

Salamon, L. M., Sokolowski, S. W., \& Anheier, H. K. (2000). Social Origins of Civil Society: An Overview. Working Papers of the Johns Hopkins Comparative Nonprofit Sector Project, 38 .

Seghers, V. (2009). La nouvelle philanthropie $\square:($ Ré)invente-t-elle un capitalisme solidaire?Editions Autrement.

Sulek, M. (2010). On the Modern Meaning of Philanthropy. Nonprofit and Voluntary Sector Quarterly, 39, $193-212$.

Tchernonog, V. (2007). Les associations en France: Poids, profils et évolutions (p. 31). Paris: Association pour le Développement de la Documentation sur l'Economie Sociale. 
ESSEC Business School Avenue Bernard Hirsch BP 50105

95021 Cergy-Pontoise Cedex France

Tél. +33(0)134433000

$\mathrm{Fax}+33(0) 134433001$

www.essec.fi

\section{ESSEC Executive Education} CNIT BP 230

92053 Paris-La Défense France

Tél. + $33(0) 146924900$

Fax +33(0)1 46924990

http://formation.essec.fr

ESSEC Business School

Singapore Campus

100 Victoria Street

National Library Building \# 13-02

Singapore 188064

essecasia@essec.fr

Tél. +6568849780

Fax +6568849781

www.essec.edu

Informations

Alison Bougi

+33 (0)134433358

bougi@essec.fr

www.essec.fr

research.center@essec.fr

ISSN 1291-9616 